\title{
Vaksin Covid-19 Sebagai Pemenuhan Hak Asasi Manusia
}

\author{
Aditya Candra Pratama Sutikno \\ Magister Hukum Universitas Islam Indonesia Yogyakarta Indonesia \\ Jln. Cik Di Tiro No. 1 Yogyakarta Indonesia \\ 19912002@students.uii.ac.id
}

\begin{abstract}
The legal issue that lies in the outbreak of the Covid-19 pandemic is contained within the scope of medical law, which is a discussion on the quality of human life in the healthcare sector. In this case, the eradication of disease, cure of disease and recovery of disease, in order to realize the maximum degree of health in the community. Efforts are taken to overcome the current Covid-19 pandemic, one of which is done through vaccination. This study further examines from a legal perspective whether the Covid-19 vaccination program can be qualified as an effort to fulfill human rights. This is a normative legal research, with a conceptual approach and qualitative analysis. This research then concludes that vaccines are widely used to prevent various diseases and help fight certain diseases, by carrying out the Covid-19 vaccine as a form of recognizing and respecting the human rights of others, the right to a decent life, safety and the right to life, and the right to sustain life.
\end{abstract}

Key Words: Covid-19 vaccine; human rights

\begin{abstract}
Abstrak
Permasalahan hukum yang terletak pada mewabahnya virus Covid-19 ini terdapat dalam ruang lingkup hukum kesehatan, yang menjadi pembahasan terhadap kualitas hidup manusia di bidang kesehatan. Dalam hal ini pemberantasan penyakit, penyembuhan penyakit dan pemulihan penyakit, untuk mewujudkan derajat kesehatan yang maksimal di masyarakat. Upaya untuk mengatasi virus Covid-19 saat ini, salah satunya dilakukan melalui vaksinasi. Penelitian ini mengkaji lebih lanjut dari perspektif hukum perihal apakah program vaksinasi Covid-19 dapat dikualifikasi ke dalam upaya pemenuhan hak asasi manusia? Penelitian ini menggunakan jenis penelitian hukum normatif, dengan pendekatan konseptual, serta dengan analisis kualitatif. Penelitian ini menyimpulkan bahwa vaksin banyak digunakan untuk mencegah berbagai macam penyakit dan membantu melawan penyakit tertentu, dengan melakukan vaksin Covid-19 sebagai bentuk mengakui dan menghormati Hak Asasi Manusia orang lain, hak atas kehidupan yang layak, keselamatan dan hak untuk hidup, serta hak untuk mempertahankan kehidupan.
\end{abstract}

Kata-kata Kunci: Hak asasi manusia, vaksin Covid-19 


\section{Pendahuluan}

Adanya upaya peningkatan kualitas hidup manusia di bidang kesehatan, merupakan suatu usaha yang sangat luas dan menyeluruh. Usaha tersebut meliputi peningkatan kesehatan masyarakat baik fisik maupun non-fisik. ${ }^{1}$ Dalam rangka meningkatkan kualitas Kesehatan manusia, dunia dikejutkan dengan munculnya penyakit gangguan pernapasan akibat infeksi virus. Penyakit baru ini pertama kali dilaporkan dari kota Wuhan, Cina pada akhir Desember 2019 lalu dan meluas hingga ke negara-negara di seluruh dunia. Word Health Organization (WHO) memberi nama virus ini dengan istilah Covid-19 yang merupakan singkatan dari Coronavirus Disease $2019 .^{2}$

Penyebaran wabah Covid 19 ini telah menyebar ke seluruh dunia termasuk Indonesia sehingga WHO menyatakan bahwa fenomena ini sebagai sebuah pandemi. Pandemi ini tidak hanya mengakibatkan permasalahan di bidang kesehatan tapi juga ekonomi. Akibat pandemi ini, pemerintah mengeluarkan kebijakan untuk membatasi ruang gerak penularan Covid-19 dengan berbagai cara, termasuk melakukan pembatasan sosial berkala besar (PSBB) yang merupakan pembatasan ruang gerak masyarakat untuk melakukan aktivitasnya di luar rumah. ${ }^{3}$

Kesehatan merupakan hak asasi setiap manusia yang harus dilindungi, dihormati, dipertahankan, dan tidak boleh diabaikan, dikurangi, atau dirampas oleh siapapun. Dalam hal ini negara berkewajiban memenuhi dan bertanggung jawab terhadap pemenuhan hak kesehatan tersebut. Pasal 1 angka 11 UU No. 39 Tahun 2009 tentang Kesehatan ialah upaya kesehatan sebagai serangkaian kegiatan yang dilakukan untuk meningkatkan derajat kesehatan masyarakat dalam bentuk pencegahan penyakit, oleh pemerintah dan/atau masyarakat.

Terkait dengan penanggulangan wabah Covid-19 pemerintah tengah memrogramkan vaksinasi bagi seluruh warga negara. Hal yang kemudian menarik adalah kaitan antara program vaksinasi dengan konsepsi Hak Asasi Manusia. Masih terdapat perbedaan pendapat mengenai konsep vaksinasi apakah didudukkan sebagai hak asasi atau kewajiban asasi. Perbedaan kedudukan ini berpengaruh pada konsekuensi yang dihadirkan lebih lanjut.

${ }^{1}$ Bahder Johan Nasution, Hukum Kesehatan Pertanggungjawaban Dokter, Cetakan 2, PT Rineka Cipta, Jakarta, 2013, hlm. 1.

2 Anika Prastyowati, "Mengenal Krakteristik Virus SARS-CoV-2 Penyebab Penyakit Covid-19 sebagai dasar Upaya Untuk Pengembangan Obat Antivirus dan Vaksin”, Bio Trends, Edisi No. 1, Vol. 11, 2020, hlm. 1.

${ }^{3}$ Indra Rahmatullah, "Jaminan Hak Kesehatan Pekerja Work Form Office Selama Masa PSBB Covid19”, Adalah: Buletin Hukum dan Keadilan, Edisi No. 1 Vol. 4, 2020, hlm. 58. 


\section{Rumusan Masalah}

Berdasarkan uraian di atas, rumusan masalah yang dikaji dalam penelitian ini adalah apakah program vaksinasi Covid-19 dapat dikualifikasi ke dalam upaya pemenuhan hak asasi manusia?

\section{Tujuan Penelitian}

Penelitian ini bertujuan untuk menganalisis kualifikasi program vaksinasi Covid-19 sebagai upaya pemenuhan hak asasi manusia.

\section{Metode Penelitian}

Penelitian ini tergolong ke dalam penelitian hukum normatif atau disebut juga dengan penelitian hukum kepustakaan secara teoritis, yang berorientasi pada apa yang dirancang oleh norma atau kaidah yang berlaku dalam masyarakat, dan menjadi acuan perilaku setiap orang. ${ }^{4}$ Bahan hukum yang diperlukan dalam penelitian ini meliputi bahan hukum primer, dan bahan hukum sekunder. Bahan hukum primer ialah semua aturan hukum yang dibentuk dan/atau dibuat secara resmi oleh suatu lembaga negara, badan-badan pemerintahan, yang demi tegaknya akan diupayakan berdasarkan daya paksa yang dilakukan secara resmi pula oleh aparat negara. ${ }^{5}$ Bahan hukum yang dimaksud yaitu meliputi: (1) Undang-Undang Dasar Negara Republik Indonesia Tahun 1945; (2) Undang-Undang tentang Hak Asasi Manusia, (3) UndangUndang Nomor 36 Tahun 2009 tentang Kesehatan, Bahan hukum sekunder yang dimaksud misalnya seperti : buku-buku, jurnal, situs-situs internet dan tulisantulisan ilmiah yang berkaitan dengan permasalahan hukum. ${ }^{6}$ Bahan hukum tertier ini ialah bahan-bahan yang termuat dalam kamus-kamus hukum, kamus besar bahasa Indonesia, kamus ilmiah dan kamus filsafat.

Pendekatan yang digunakan dalam penelitian ini ialah, Pendekatan konseptual (Conceptual Approach). Pendekatan dengan mencari dan menelaah pandangan-pandangan dan doktrin-doktrin. ${ }^{7}$ Pendekatan undang-undang (Statute Aprroach). Pendekatan ini menjadi dasar membantu peneliti memahami asas-asas dalam peraturan perundang-undang dalam melakukan analitis. ${ }^{8}$ Analisis yang digunakan dalam penelitian ini adalah analisis kualitatif, yakni

${ }^{4}$ Ishaq, Metode Penelitian Hukum, Cetakan Kesatu, Alfabeta, Bandung, 2017, hlm. 66.

5 Soetandyo Wignjosoebroto, Hukum Konsep dan Metode, Cetakan Pertama, Setara Press, Malang, 2013, hlm. 67.

${ }^{6}$ Soetandyo Wignjosoebroto, Ibid., hlm. 69.

7 Peter Mahmud Marzuki, Penelitian Hukum Edisi Revisi, Cetakan ke-10, Prenadamedia Group, Jakarta, 2015, hlm. 177.

8 Peter Mahmud Marzuki, Ibid., hlm. 137. 
adalah cara menganalisis data yang bersumber dari bahan hukum yang berdasarkan kepada konsep, teori, peraturan perundang-undangan, doktrin, prinsip hukum, pendapat pakar atau pandangan peneliti sendiri. ${ }^{9}$

\section{Hasil Penelitian dan Pembahasan}

\section{Program Vaksinasi Covid-19 sebagai Upaya Pemenuhan Hak Asasi Manusia}

Vaksin merupakan agen biologis yang memiliki respon imun terhadap antigen spesifik yang berasal dari patogen penyebab penyakit menular. Edaward Jenner mengembangkan vaksin pertama pada 1796 yaitu menggunakan cacar sapi untuk diinokulasi terhadap cacar. Hal tersebut pada akhirnya menjadi suatu agen pemberantas cacar secara global, yang secara resmi dinyatakan pada tahun 1980. Sejak itu vaksin telah membantu menekan penyebaran beberapa penyakit menular termasuk polio. Vaksin merupakan sesuatu yang dianggap sebagai salah satu kemenangan terbesar dalam sejarah kedokteran. Hingga hari ini, seluruh manusia hidup dalam periode pengembangan vaksin yang paling sukses. Vaksin sudah banyak digunakan untuk mencegah berbagai macam penyakit. ${ }^{10}$

Kewajiban negara mengimplementasikan norma-norma HAM pada hak atas kesehatan, harus memenuhi prinsip-prinsip seperti: 1. Ketersediaan pelayanan kesehatan, 2. Aksebilitas, 3. Penerimaan, 4. Kualitas. Dalam bentuk kewajiban negara untuk memenuhi hak atas kesehatan diinternalisasikan dalam bentuk kebijakan pemerintah dengan prinsip: a. menghormati hak atas kesehatan, $b$. melindungi hak atas kesehatan, dan c. memenuhi hak atas kesehatan. ${ }^{11}$

Perlu disadari bahwa penerapan HAM dibatasi oleh HAM orang lain. Setiap manusia yang menyadari dirinya sebagai manusia seutuhnya memiliki kewajiban untuk mengakui dan menghormati HAM orang lain, demi terlaksana dan tegaknya HAM itu sendiri. ${ }^{12}$

Secara historikal dan filosofikal, penyusunan rezim hukum HAM Internasional sangat di pengaruhi dan berakar dari pemikiran teori hak kodrati (natural rights theory) yang dicetuskan Thomas Aquinas yang lalu dikembangkan oleh Hugo Grotius serta John Locke dalam teori kontrak sosial miliknya. Grotius dalam mengembangkan teori hukum kodratnya memutus asal-usul teisme seperti dipostulasikan oleh Aquinas, sehingga menjadi produk pemikiran sekuler yang rasional. Menurut postulasi Grotius, setiap orang harus menikmati hak-haknya

\footnotetext{
${ }^{9}$ Ishaq, Op. Cit., hlm. 69-70.

10 Indah Pitaloka Sari, Sriwidodo, "Perkembangan Teknologi Terkini Dalam Mempercepat Produksi Vaksin Covid-19”, Majalab Farmasetika, 5 (5) 2020, hlm. 206.

${ }^{11}$ Fheriyal Sri Isriawaty, "Tanggung Jawab Negara Dalam Pemenuhan Hak Atas Kesehatan Masyarakat Berdasarkan Undang-Undang Dasar Negara Republik Indonesia Tahun 1945”, Jurnal Ilmu Hukum Legal Opinion, Edisi No. 2, Vol. 3, 2015, hlm. 5.

12 A. Widiada Gunakaya, Hukum Hak Asasi Manusia, Edisi 1, ANDI, Yogyakarta 2017, hlm. 2.
} 
dengan bantuan masyarakat untuk mempertahankan hak hidup, hak kebebasan, hak miliknya. Sedangkan menurut Locke, setiap individu oleh alam dikarunia hak yang melekat atas hidup (Hak hidup), kebebasan (hak kebebasan), dan kepemilikan (hak kepemilikan) yang tidak dapat dicabut oleh negara. ${ }^{13}$

Generasi pertama HAM melahirkan hak kebebasan di bidang hak sipil dan hak politik (hak sipol). Hak ini muncul sebagai suatu tuntutan dari rakyat untuk melepaskan diri dari kekuasaan absolutisme negara dan kekuasaan-kekuasaan sosial lainnya yang muncul dalam revolusi di Amerika Serikat dan Perancis pada abad ke 17 dan 18. Oleh sebab itu hak-hak ini disebut dengan hak klasik yang diperjuangkan untuk melindungi kehidupan pribadi manusia atau untuk menghormati otonomi setiap orang, sehingga orang yang bersangkut memiliki kedaulatan secara pribadi (kedaulatan individual). Termasuk di dalam hak-hak generasi pertama ini ialah, hak hidup, kedaulatan jasmani, hak kebebasan bergerak, hak suaka dari penindasan, perlindungan terhadap hak milik, kebebasan berpikir, beragama dan berkeyakinan, kebebasan untuk berkumpul dan menyatakan pikiran, hak bebas dari penahanan dan penangkapan sewenangwenang, hak bebas dari penyiksaan, hak bebas dari hukum yang berlaku surut, dan hak mendapatkan proses peradilan yang adil. Bahwa pada sejatinya hak-hak yang dimaksud menjamin kebebasan bagi individu untuk mewujudkannya, maka dari itu individu itu sendirilah yang berhak menentukannya.

Generasi kedua HAM ialah hak persamaan di bidang hak-hak ekonomi, sosial dan budaya (ekosob). Hak-hak ini diperjuangkan sebagai tuntutan agar negara menyediakan pemenuhan terhadap kebutuhan dasar setiap orang, mulai dari makan sampai kesehatan. ${ }^{14}$ Dalam Mukadimah DUHAM ada dua hal pokok yang menjadi pertimbangan pada ketujuh alinea pertama ialah:

1. Bahwa sesungguhnya, hak kodrati setiap manusia adalah berkat pemberian Tuhan, yang tidak dapat dipisahkan dari hakikat manusia itu sendiri;

2. Oleh karena itu, setiap manusia berhak atas kehidupan yang layak, kebebasan, keselamatan, dan kebahagian pribadi.

Pasal 3 sampai dengan Pasal 21 DUHAM berisi mengenai hak sipil dan politik, seperti hak hidup, hak kebebasan berpendapat, hak berorganisasi, hak untuk dipilih dan memilih, serta hak untuk duduk dalam pemerintahan. ${ }^{15}$ Salah satu dari delapan hak asasi manusia yang tergolong hak asasi fundamental yaitu

${ }^{13}$ Ibid., hlm. 6.

${ }^{14}$ Ibid., hlm. 18-19.

15 Max Boli Sabon, Hak Asasi Manusia Bahan Pendidikan Untuk Perguruan Tinggi, Cetakan Kedua, Universitas Katolik Indonesia Atma Jaya, Jakarta 2019, hlm. 17-18. 
seperti hak untuk hidup. ${ }^{16}$ Isi dari piagam madinah yang dapat ditarik beberapa ketentuan hak asasi manusia salah satunya ialah pengakuan hak hidup. ${ }^{17}$

Melihat dari pemikiran John Locke untuk membebaskan manusia dari suasana mencekam dengan menggagaskan bahwa manusia bukanlah lawan (homo homini lupus) melainkan kawan, makhluk yang beradab, makhluk yang berakal budi (homo sapiens), dengan dikatakan manusia sebagai homo sapiens memiliki tiga macam hak seperti hak asasi, hak untuk hidup, hak atas kebebasan atau kemerdekaan, dan hak untuk memiliki sesuatu. Kemudian ditegaskan lagi bahwa hak untuk memiliki sesuatu tidak hanya memiliki sesuatu barang, akan tetapi juga kehidupan dan kebebasan. Namun selain hal itu ada lima hak lain lagi dalam property rights, yaitu seperti nyawa, badan, kemerdekaan, kehormatan, dan benda. ${ }^{18}$

Perjanjian internasional mengenai HAM diatur tiga karakter HAM berdasarkan bentuk pembatasannya salah satu di antara tiga tersebut ialah hak yang dapat dikurangi melalui klausul pembatasan tertentu dengan alasan khusus, seperti kepentingan umum, keamanan nasional, kesehatan dan moral publik baik dalam keadaan normal atau situasi damai. Klausul pembatasan ini hanya berlaku terhadap hak-hak tertentu dan tidak mensyaratkan tindakan khusus bagi negara untuk memberlakukannya. ${ }^{19}$

R. J. Vincent seperti dikutip oleh Howard mengemukakan HAM dasar dari pengertian tentang kebutuhan dasar manusia dan dari teorinya tentang apa yang strategis diperlukan untuk melindungi HAM. Ia menegaskan bahwa salah satu hak dasar ialah hak untuk hidup. Ia menambahkan bahwa hak tentatif yakni hak atas kebebasan, maksudnya ialah "bukan dalam pengertian heroik kebebasan atau kematian, tetapi dalam pengertian bahwa hak tersebut penting untuk bisa menikmati hak yang lain, termasuk hak untuk hidup. ${ }^{20}$

Basic Rights (hak dasar) adalah hak yang menjadi prioritas mutlak dalam masyarakat nasional dan internasional. Hak dalam pengertian ini meliputi semua hak yang diperlukan untuk memenuhi kebutuhan manusia baik dalam arti material maupun non material, dan bilamana hak-hak itu tidak ada maka manusia tidak dapat hidup secara bermartabat. Hak-hak seperti ini ialah hak hidup, hak atas keamanan minimum, hak untuk tidak diganggu, bebas dari perbudakan dan perhambaan, bebas dari penyiksaan, pengurangan kebebasan

${ }^{16}$ Ibid., hlm. 30.

${ }^{17}$ Ibid., hlm. 25.

${ }^{18}$ Ibid., hlm. 19-20.

19 Muhammad Ashri, Hak Asasi Manusia Filosofi, Teori \& instrumen dasar, Cetakan Pertama, CV. Social Politic Genius, Makasar, 2018, hlm. 5.

${ }^{20}$ Ibid., hlm. 6-8. 
yang tidak berdasar hukum, diskriminasi dan tindakan lain yang mengurangi martabat manusia. ${ }^{21}$

Undang-Undang Nomor 36 Tahun 2009 tentang Kesehatan, sebagaimana yang berbunyi dalam konsideran huruf a yaitu, bahwa kesehatan merupakan hak asasi manusia dan salah satu unsur kesejahteraan yang harus diwujudkan sesuai dengan cita-cita bangsa Indonesia sebagaimana dimaksud dalam pancasila dan Undang-Undang Dasar Negara Republik Indonesia Tahun 1945. Pasal 1 angka 1, menentukan kesehatan adalah keadaan sehat, baik secara fisik, mental, spritual maupun sosial yang memungkinkan setiap orang untuk hidup produktif secara sosial dan ekonomis. Pasal 4, setiap orang berhak atas kesehatan.

Pasal 9 ayat (1 dan 2), bahwa setiap orang berkewajiban ikut mewujudkan, mempertahankan, dan meningkatkan derajat kesehatan masyarakat yang setinggi-tingginya. Pelaksanaannya tersebut meliputi upaya kesehatan perseorangan, upaya kesehatan perorangan, upaya kesehatan masyarakat, dan pembangunan berwawasan kesehatan. Pasal 11, setiap orang berkewajiban berprilaku hidup sehat untuk mewujudkan, mempertahankan, dan memajukan kesehatan yang setinggi-tingginya. Pasal 3, pembangunan kesehatan bertujuan untuk meningkatkan kesadaran, kemauan, dan kemampuan hidup sehat bagi setiap orang agar terwujud derajat kesehatan masyarakat yang setinggi-tingginya, sebagai investasi bagi pembangunan sumber daya manusia yang produktif secara sosial dan ekonomis.

Pasal 6, setiap orang berhak mendapatkan lingkungan yang sehat bagi pencapaian derajat kesehatan. Pasal 12, setiap orang berkewajiban menjaga dan meningkatkan derajat kesehatan bagi orang lain yang menjadi tanggung jawabnya. Pasal 38 ayat (1 dan 2), pemerintah mendorong dan mengarahkan pengembangan perbekalan kesehatan dengan memanfaatkan potensi nasional yang tersedia. Pasal 46, untuk mewujudkan derajat kesehatan yang setinggitingginya bagi masyarakat, diselenggarakan upaya kesehatan yang terpadu dan menyeluruh dalam bentuk upaya kesehatan perseorangan dan upaya kesehatan masyarakat.

Pasal 48, penyelenggaraan upaya kesehatan sebagaimana dimaksud dalam Pasal 47 dilaksanakan melalui dua diantaranya ialah huruf $\mathrm{c}$ dan d yaitu, peningkatan kesehatan dan pencegahan penyakit, dan penyembuhan penyakit dan pemulihan kesehatan. Pasal 52 ayat (1) huruf a dan b yaitu pelayanan kesehatan perseorangan dan pelayanan kesehatan masyarakat. Pasal 53 ayat (1 dan 2), pelayanan kesehatan perseorangan ditujukan untuk menyembuhkan penyakit dan memulihkan kesehatan perseorangan dan keluarga, sedangkan 
pelayanan kesehatan masyarakat ditujukan untuk memelihara dan meningkatkan kesehatan serta mencegah penyakit suatu kelompok dalam masyarakat. Pasal 62 ayat (2), pencegahan penyakit merupakan segala bentuk upaya yang dilakukan oleh pemerintah, pemerintah daerah, dan/atau masyarakat untuk menghindari atau mengurangi risiko, masalah, dan dampak buruk akibat penyakit.

Salah satu faktor yang mempengaruhi derajat kesehatan masyarakat ialah pelayanan kesehatan sebab keberadaan fasilitas kesehatan menentukan pelayanan pemulihan kesehatan, pencegahan penyakit, pengobatan, dan keperawatan. Pelayanan kesehatan memiliki pengaruh terhadap lokasi suatu tempat, bagaimana seseorang itu dapat menjangkau pelayanan kesehatan tersebut. Semakin mudah menjangkau akses pelayanan kesehatan, maka semakin baik derajat kesehatan tersebut, begitu pula sebaliknya. Adapun alasan pelayanan kesehatan yang dapat mempengaruhi kesehatan dapat dilihat salah satu diantaranya ialah sebagai berikut.

Tersedianya sarana dan prasarana kesehatan yang baik akan memudahkan masyarakat dalam mendapatkan pelayanan kesehatan yang bermutu dan berkualitas. Adapun yang menjadi sasaran kesehatan masyarakat seperti individu, keluarga, serta kelompok khusus baik yang sehat maupun yang mempunyai masalah. ${ }^{22}$ Adanya salah satu sasaran pembangunan menuju Indonesia sehat ialah derajat kesehatan seperti menaiknya secara bermakna umur harapan hidup, menurunya angka kematian ibu dan bayi, menurunya angka kesakitan tanpa penyakit penting, merendahnya angka kecacatan dan ketergantungan, meningkatnya status gizi masyarakat, serta merendahnya angka infertilitas. ${ }^{23}$

RNA vaksin menjadi jenis vaksin yang paling banyak digunakan dalam program pengembangan vaksin Covid-19. Moderna Inc adalah perusahaan bioteknologi yang berbasis di Cambridge, Massachusetts yang merupakan salah satu perusahaan bioteknologi yang juga fokus pada mRNA dari virus SARAS CoV-2. Moderna Inc telah mengembangkan vaksin mRNA untuk Covid-19 yang disebut mRNA-1273. Hingga saat ini calon bakal vaksin dari Moderna Inc adalah calon bakal vaksin yang pertama mencapai tahapan uji klinis dibandingkan program vaksin lainnya. Dalam hal ini adanya kerjasama antara institusi, akademisi, pemerintah, dan perusahaan di berbagai dunia diharapkan mampu menghadirkan vaksin Covid-19 mengingat segala keterkaitan inilah yang kemudian mampu mengidentifikasi SARS-CoV-2 dalam waktu yang tidak lebih

22 Rina Sari, Dasar Ilmu Kesehatan Masyarakat Untuk Mahasiswa Kebidanan, PT. Pustaka Baru, Yogyakarta, tt, hlm. 11-12.

${ }^{23}$ Ibid., hlm. 22. 
dari tiga bulan. Sehingga dengan demikian hal ini menjadi harapan bagi dunia untuk menciptakan vaksin virus SARS-CoV-2, sehingga pandemi dari COVID-19 dapat segera berakhir. ${ }^{24}$

Vaksin adalah sebuah zat atau subtansi yang membantu melawan penyakit tertentu. Vaksin mengutip dari Web MD, mengandung virus yang dilemahkan atau yang sudah mati. Virus ini membantu untuk mendeteksi virus yang menyerang tubuh. Sistem imun bisa mudah melawan virus yang menginfeksi tubuh. ${ }^{25}$ Vaksinasi ialah pemberian vaksin (antigen) yang dapat merangsang pembentukan imunitas (antibodi) sistem imun di dalam tubuh. Vaksinasi sebagai upaya pencegahan primer yang sangat handal mencegah penyakit yang dapat dicegah dengan vaksinasi. Adanya prosedur vaksinasi yang benar diharapkan akan diperoleh kekebalan yang optimal, penyuntikan yang aman dan kejadian Ikutan Pasca Imunisasi (KIPI) yang minimal. Sebetulnya, sistem kekebalan tubuh terhadap suatu penyakit bisa terbentuk secara alami saat seseorang terinfeksi virus atau bakteri penyebabnya. Namun, infeksi virus corona memiliki risiko kematian dan daya tulaar yang tinggi. Maka diperlukan cara lain untuk membentuk sistem kekebalan tubuh, yaitu vaksinasi.

Vaksinasi Covid-19 dilakukan setelah kepastian keamanan dan keampuhannya ada, merupakan upaya untuk menurunkan kesakitan dan kematian serta mendorong terbentuknya kekebalan kelompok. ${ }^{26}$ Kesemuanya dari kumpulan prioritas di atas mendapat vaksin Covid-19, vaksinasi akan dilanjutkan ke kumpulan penerima vaksin Covid-19 lainnya, mulai dari penduduk di daerah yang banyak kasus Covid-19 sampai ke semua bagian seluruh Indonesia. ${ }^{27}$ Dalam Al-Qur'an, Al-Qasas (QS. 28 ayat 59) arti yang terkandung didalamnya ialah:

"Dan Tuhanmu tidak akan membinasakan kota-kota sebelum dia mengutus di ibu kota itu seorang rasul yang membacakan ayat-ayat kami kepada mereka dan tidak pernah (pula) kami membinasakan kota-kota, kecuali penduduknya dalam keadaan melakukan kezaliman. ${ }^{28}$

Hal pertama yang perlu di ketahui dan di pahami bahwa vaksin sebagai zat atau subtansi yang membantu melawan penyakit tertentu, sebab vaksin

\footnotetext{
24 Armanto Makmun dan Siti Fadhilah Hazhiyah, "Tinjauan Terkait Pengembangan Vaksin Covid-19”, Molucca Medica, Edisi No. 2 Vol. 13, hlm. 58.

25 Siti Nur Aidah, "Bacaan Wajib! Vaksin Corona”, Vol. 110, Yogyakarta-Jawa Timur, KBM Indonesia, 2021, hlm. 4 .

${ }^{26}$ M. Rifaldi, Pandemi Virus Corona, Cetakan Ke-01, Yayasan Sahabat Alam Rafflesia, Bengkulu, 2021, hlm. 86.

${ }^{27}$ Ibid., hlm. 88.

28 Muchamad Iksan, “Asas Legalitas Dalam Hukum Pidana: Studi Komparatif Asas Legalitas Hukum Pidana Indonesia dan Hukum Pidana Islam (Jinayah)", Jurnal Serambi Hukum, Edisi No. 01 Vol. 11, Februari-Juli, 2017, hlm. 20.
} 
mengandung vitrus yang dilemahkan atau yang sudah mati. Kemudian virus itu berfungsi untuk mendeteksi virus yang menyerang tubuh. Sistem imun bisa mudah melawan virus yang menginfeksi tubuh. Dengan demikian adanya vaksin Covid-19 bermanfaat sebagai yang dapat merangsang pembentukan imunitas atau antibodi, sistem imun didalam tubuh. Hadirnya vaksinisasi sebagai upaya pencegahan primer yang sangat handal mencegah penyakit yang dapat dicegah dengan vaksinisasi. Adanya prosedur vaksinisasi yang benar diharapkan atau diperoleh kekebalan yang maksimal, dengan sistem kekebalan tubuh terhadap suatu penyakit cara untuk membentuk sistem kekebalan tubuh yaitu vaksinisasi.

Upaya peningkatan kualitas hidup manusia dibidang kesehatan menjadi suatu usaha yang sangat luas dan menyeluruh, usaha tersebut seperti peningkatan kesehatan masyarakat baik fisik maupun non fisik. Hak atas kehidupan dan kesehatan menjadi suatu hak negatif. Hak tersebut akan membawa konsekuensi bagi orang lain untuk berbuat sesuatu atas layanan kesehatan. Sebab hak atas layanan kesehatan disebut juga hak sosial. Hak atas kehidupan menjadi hak yang sangat penting.

Dengan melakukan vaksin Covid-19 dapat (untuk mengakui dan menghormati HAM orang lain, demi terlaksana dan tegaknya HAM itu sendiri, sebab setiap orang harus menikmati hak-haknya dengan bantuan masyarakat untuk mempertahankan hak hidup). Locke berpendapat setiap individu oleh alam dikarunia hak yang melekat atas hidup (hak hidup). Dalam Mukadimah DUHAM ialah setiap manusia berhak atas kehidupan yang layak, keselamatan.

(1)Adanya satu diantara beberapa hak lainnya seperti terdapat dalam Pasal 3 sampai dengan 21 yaitu hak hidup. Kemudian salah satu dari delapan hak asasi manusia ialah hak untuk hidup. Isi dari piagam madinah salah satunya ketentuannya ialah pengakuan hak hidup.

(2)Dalam Basic Rights (hak dasar) adalah yang dimaksud ialah hak-hak seperti hak hidup.

(3)Melihat dari pemikiran John Locke bahwa untuk membebaskan manusia dari suasana mencekam bukanlah lawan (homo homini lupus), nama melainkan kawan, makhluk yang beradab, makhluk yang berakal budi (homo sapiens). Dikatakan manusia sebagai homo sapiens memiliki tiga macam hak salah satunya hak untuk hidup. Bahwa ditegaskan pula kehidupan merupakan hak untuk memiliki.

(4)Dalam Undang-Undang Nomor 39 Tahun 1999 tentang Hak Asasi Manusia seperti dalam konsideran huruf b, c, Pasal 4, Pasal 8, Pasal 9 ayat (1 dan 2), serta Pasal 35. Menjelaskan bahwa HAM merupakan hak dasar yang secara kodrati melekat pada diri manusia dan harus dilindungi. Bahwa manusia juga mempunyai kewajban dasar antara manusia yang satu dan yang lain terhadap masyarakat secara keseluruhan dalam kehidupan bermasyarakat. hak untuk hidup, perlindungan, setiap orang berhak untuk hidup, mempertahankan hidup, dan meningkatkan taraf kehidupannya. seperti 
setiap orang berhak atas lingkungan hidup yang baik dan sehat. menghormati, melindungi dan melaksanakan sepenuhnya Hak Asasi Manusia dan kewajiban dasar manusia.

(5)Dalam Undang-Undang Nomor 36 Tahun 2009 tentang Kesehatan terdapat didalam konsideran huruf a, Pasal 1 ayat (1) dan Pasal 4 dijelaskan bahwa kesehatan merupakan Hak Asasi Manusia dan salah satu unsur kesejahteraan yang harus diwujudkan sesuai dengan cita-cita bangsa Indonesia sebagaimana dimaksud dalam pancasila dan Undang-Undang Dasar Negara Republik Indonesia Tahun 1945. kesehatan adalah keadaan sehat, setiap orang berhak atas kesehatan.

(6)Vaksin dianggap sebagai suatu kemenangan besar dalam sejarah kedokteran. Oleh karena itu vaksin sudah banyak digunakan untuk mencegah berbaagai macam penyakit.

\section{Penutup}

Penelitian ini menyimpulkan bahwa vaksin Covid-19 dapat diklasifikasikan sebagai hak asasi manusia dengan melihat dari perspektif bagaimana vaksin Covid-19 ditujukan dengan maksud mempertahankan hak untuk hidup, kehidupan yang layak dan keselamatan, pengakuan hak hidup. Jika dilihat dari pemikiran John Locke bahwa salah satu hak homo sapiens ialah hak untuk hidup, pemberian vaksin Covid-19 ini pun juga sebagai perlindungan setiap orang berhak untuk hidup, mempertahankan hidup dalam mendapatkan imun atau kekebalan tubuh terhadap virus Covid-19 ini.

Kesehatan merupakan Hak Asasi Manusia dan salah satu unsur kesejahteraan yang harus diwujudkan sesuai dengan cita-cita bangsa Indonesia sebagaimana dimaksud dalam pancasila dan Undang-Undang Dasar Negara Republik ndonesia Tahun 1945. Oleh karena itu, vaksinasi menjadi sebab setiap orang berhak atas kesehatan, sekaligus menjadi kewajiban moral bagi setiap orang untuk ikut serta program vaksinasi agar terwujud kekebalan komunal (herd immunity) bagi seluruh warga negara dunia.

\section{Daftar Pustaka}

\section{Buku}

Adelina Siregar, Rospita dan Herniwati dan dkk. Etika Profesi dan Hukum Kesehatan, Cetakan Pertama, Widina Bhakti, Bandung 2020.

Ishaq, Metode Penelitian Hukum, Cetakan Kesatu, Alfabeta, Bandung 2017.

M., Rifaldi, Pandemi Virus Corona, Cetakan Ke-01, Yayasan Sahabat Alam Rafflesia, Bengkulu 2021.

Marzuki Peter, Mahmud, Penelitian Hukum Edisi Revisi, Cetakan ke-10, Prenadamedia Group, Jakarta 2015. 
Muhammad, Ashri, Hak Asasi Manusia Filosofi, Teori \& Instrumen Dasar, Cetakan Pertama, CV. Social Politic Genius (SIGn), Makassar 2018.

Nasution Bahder, Johan, Hukum Kesehatan Pertanggung Jawaban Dokter, Cetakan 2, Rineka Cipta, Jakarta 2013.

Rina, Sari, Dasar Ilmu Kesehatan Masyarakat Untuk Mahasiswa Kebidanan, PT. Pustaka Baru, Yogyakarta, tt.

Soetandyo, Wignjosoebroto Hukum Konsep dan Metode, Cetakan Pertama, Setara Press, Malang, 2013.

Yusuf, Hanafiah dan Amir Amri, Etika Kedokteran \& Hukum Kesehatan, Diterbitkan Pertama Kali, Edisi 3, Buku Kedokteran EGC, Jakarta 1999.

Widiada, A. Gunakaya, Hukum Hak Asasi Manusia, Edisi 1, ANDI, Yogyakarta, 2017.

\section{Jurnal dan Majalah}

Pitaloka Sari Indah, Sriwidodo, "Perkembangan Teknologi Terkini Dalam Mempercepat Produksi Vaksin Covid-19", Majalah Farmasetika, 5 (5) (2020).

Prastyowati Anika, "Mengenal Krakteristik Virus SARS-CoV-2 Penyebab Penyakit Covid-19 sebagai dasar Upaya Untuk Pengembangan Obat Antivirus dan Vaksin", Bio Trends, Edisi No. 1, Vol. 11, (2020).

Rahmatullah Indra, "Jaminan Hak Kesehatan Pekerja Work Form Office Selama Masa PSBB Covid-19", Adalah: Buletin Hukum dan Keadilan, Edisi No. 1 Vol. 4, (2020).

Sri Isriawaty Fheriyal, "Tanggung Jawab Negara Dalam Pemenuhan Hak Atas Kesehatan Masyarakat Berdasarkan Undang-Undang Dasar Negara Republik Indonesia Tahun 1945", Jurnal Ilmu Hukum Legal Opinion, Edisi No. 2, Vol. 3, (2015).

\section{Undang-Undang}

Undang-Undang Dasar Negara Republik Indonesia Tahun 1945.

Undang-Undang Nomor 39 Tahun 1999 Tentang Hak Asasi Manusia. 